\title{
Competitive Sustainability of Food and Beverage SMEs in South Sulawesi
}

\author{
Muhammad Toaha ${ }^{1}$, Haris Maupa ${ }^{2}$, Nurdin Brasit ${ }^{3}$, Idrus Taba ${ }^{4}$ and Andi Aswan ${ }^{5}$
}

\author{
${ }^{1}$ Hasanuddin University, Indonesia. \\ ${ }^{2}$ Hasanuddin University, Indonesia. \\ ${ }^{3}$ Hasanuddin University, Indonesia. \\ ${ }^{4}$ Hasanuddin University, Indonesia. \\ ${ }^{5}$ Hasanuddin University, Indonesia.
}

\begin{abstract}
The study is aimed to identify and solve the problems of why the food and beverage SMEs in South Sulawesi are not able to have a longer sustainability in comparison to the large one and how an integrated model of the sustained competitive advantage is built for SMEs of food and beverage should be built. On the basis of theoretical and empirical findings from many cases in the world, the study identifies four latent variables measured by nineteen indicators possibly affecting the sustainability of food and beverage SMEs in the South Sulawesi. With the use of theoretical approach, the identified four latent variables are constructed resulting six hypotheses. Firstly, the latent variable of the product is related to two latent variables that are the business-specific condition and the sustainable competitive advantage. The latent variables of the process-specific condition are associated with three latent variables that are the product-specific condition, the business-specific condition, and the sustained competitive advantage. The last is the latent variable of the businessspecific condition is related to the sustained competitive advantage. Each latent variable studied is reflected by indicators and the whole the fourth latent variables are measured by 19 indicators. Keywords: Sustained Competitive Advantage, Product, Process, and Business-Specific Condition
\end{abstract}

\section{Introduction}

This study aims to assist food and beverage SMEs in the South Sulawesi in an effort to improve their business continuity. The issue of sustainability is the main issues currently faced by this business. Unlike the large food and beverage businesses, SMEs food and beverage has a high level of competition (Yuli, 2006). The businesses do not only compete with large businesses (Sudaryanto \& Wijayanti, 2013) but also compete with other SMEs that provide food and beverage products. This then affects the vulnerability of business continuity. To illustrate, it is very easy for an entrepreneur to set up the business without spending a lot of investment. It is; therefore, new businesses often suddenly appear and threat openly the sustainability of existing businesses. This is also reinforced by the low exit costs so that businesses that have long been operating can also suddenly close.

Another, SMEs of food and beverage play an important role in the regional economy (Sondakh, Christiananta, \& Ellitan, 2017). Different from large food and beverage businesses, SMEs mostly use raw materials and auxiliary materials from local products that are generally obtained in traditional markets (Sudaryanto \& Wijayanti, 2013). This indicates that food and beverage SMEs have a link with other businesses in the upstream. The connection is established between traders in traditional markets and indirectly with food commodity suppliers as well as farmers in the village.

Apart from the phenomenon, the study of food and beverage industry in Indonesia until recently was widely studied. However, in general, the existing studies stress different objects and focus. Viewed from the research object, research related to food and beverage business mostly focus on large businesses (Salim et al, 2018; Diana, 2017). In fact, there are differences in the nature of business between large one and SMEs (Meilani \& Simanjuntak, 2012; Kristiyanti, 2012), some of which are the ease to start the business, and the ease to exit the business, and the use of local content (Latifah, 2016 and Sudaryanto \& Wijayanti, 2013). 
Furthermore, research on food and beverage SMEs is found mostly related to business performance (Sondakh, Christiananta, \& Ellitan, 2017 and Indris \& Primiana, 2015) which are measured in terms of finance, marketing (Jauhari, 2014) and operational aspects (Latifah, 2016). Studies focusing on the sustained competitive advantage for SMEs of food and beverage in Indonesia until recently is not widely studied. To the best of our knowledge, there are only a few pieces of literature that discuss the competitiveness of SMEs of food and beverage, such as Matrutty et al., (2018) which emphasizes the importance of production factors such as quality raw materials and the ability to produce quality products.

Based on the given above, the study focuses on the factors leading to a sustained competitive advantage for SMEs of food and beverage in South Sulawesi. The study also addresses how the integrated model of the sustained competitive advantage for SMEs of food and beverage is built by taking into account the product-specific condition, the process-specific condition, and the businessspecific condition.

\section{Research Methodology}

This research is a library research. Research resources are books, journals and articles on the internet.

\section{Result and Discussion}

Sustainable Competitive Advantage. Businesses that are currently superior might not be able to survive and remain superior in the long term. the existing superior business may not be superior in the long run because current advantages can be easily imitated or applied by competitors (Barney, 1986). For this reason, in order to survive in the long term, companies are required to have sustained competitive advantages (Barney, 1986, 1991). It is a sustainable advantage that is not easy to be imitated by other businesses so that the company can excel in a longer period of time. The sustained competitive advantage is very crucial in particularly to businesses facing a high level of competition, such as the food and beverage industry.

There is an extensive literature has discussed sustained competitive advantages. In general, the existing studies discussed internal capabilities mostly. Among them are Bharadwaj, Varadarajan \& Fahy (1993) use a distinctive measure of organizational resources and resources for service companies in service companies. Resource-based viewers like Amit \& Scgoemaker (1993) and (Barney (1991) are also internal factors such as resources and capabilities of a business viewed from a strategic factor.

The study measuring sustainable competitive advantage from the point of view of engagement are intertwined with stakeholders, tacit knowledge, and business reputation. To stakeholders, it has been studied currently by some literatures such as Jones, Harrison \& Felps (2018) and Long, Looijen \& Blok (2018). It has also been previously amplified by Hendry $(2001,2004)$ that stated the relationship built with fairness, trustworthiness, loyalty, care, and respect will be likely to impact positive financial performance continuously. This study measures the advantages of connection that are intertwined with stakeholders, namely suppliers, consumers, and employees (Kumar \& Pansari, 2016 and Grekova et al, 2016). These three stakeholders are believed to be the key important factor to affect the sustained competitive advantage of SMEs in the food and beverage.

Like stakeholder, tacit knowledge as a source of sustained competitive advantage also has been studied by a number of literatures. Maskell, P., \& Malmberg, A. (1999) Envoy the ability of people in an organization with knowledge creation leads to the ability to direct resources in a competitive way. This also has been echoed by (Rodriguez Perez, \& Ordóñez de Pablos, (2003) and Man, Lau, \& Chan (2002).

With respect to business reputation, numbers of researchers have been noted as a way to obtain sustained competitive advantage. Hoffman, Hoelscher, \& Sorenson (2006) noted that the family business in terms of family capital has a reputation over non-family businesses. Hall (1993) stresses that intangible assets lead to sustained competitive advantages. McWilliams, A., \& Siegel, D. S. 
(2011) recorded that reputation obtained from social corporate responsibility drives a firm into a position of sustained competitive advantage. Still, Roberts, P. W., \& Dowling, G. R. (2002) also found that reputation assumptions have a sustained superior profitability.

The Product-Specific Condition. The competitiveness of business can be built through the products produced (Porter, 1985 and Eniola \& Ektebang, 2014). Quality products, low prices (Eniola \& Ektebang, 2014 and Meilani \& Simanjuntak, 2012), attractive displays (Han, Nguyen, \& Lee, 2015), different and appetizing (Mutunga \& Minja, 2014) are some indicators leading consumers to consume the product in a sustainable manner (Porter, 1985 and Min \& Min, 2011). In addition, the way of presentation also drives up buying behavior (Hanaysha, 2016). The quick delivery time is believed to affect the decision of buyers (Hanaysha, 2016).

H1. The more innovative and attractive the product, the higher the reputation of business.

A business reputation comes from its ability to promote the products produced. The reputation is a result of a combination of products and business characteristics (Rubio, Oubiña \& Villaseñor, 2014). Attractive attributes of a product drive up an effort of customer behavior to use or consume directly the products produced (Han, Nguyen, \& Lee, 2015 and Tong \& Wong, 2014). Product attributes are crucial factors in food and beverage businesses (Tong \& Wong, 2014). Indicators of taste, product attractiveness (Han, Nguyen, \& Lee, 2015), low cost (Yim, Lee \& Kim, 2014), and products appetizing (Han, Nguyen, \& Lee, 2015; Mutunga \& Minja, 2014 and Tong \& Wong, 2014), and quick delivery time (Hanaysha, 2016) will increase brand which in turn drive up business reputation.

$\mathrm{H} 2$. The more innovative and attractive the product, the more possible to have sustained competitive advantage.

In food and beverage products, customers are very interested in the looking and taste attached to a product. When the appearance is attractive, there is the possibility to taste the product and it will, in turn, increase the possibility to consume regularly (Han, Nguyen, \& Lee, 2015; Tong \& Wong, 2014 and Min \& Min, 2011). It will lead to increase the sustained competitive advantage of business (Min \& Min, 2011). Differently, a common food and beverage product may have customers, but the frequency of purchasing behavior may be lower compared to attractive and tasty food. Besides both factors given previously, the delivery time is also an important note on food and beverage products. Food and beverage are served in a quick time could lead to attracting customers (Hanaysha, 2016). Customers generally do not want to spend the time to wait for foods, when they come, they need to have the served right on the time. When a business could pay attention to the delivery time, it could create an impression that may not be forgotten by customers (Untaru, Ispas \& NEACŞU, 2012). The impression will increase the desire to consume the products and services more often. This, in turn, lead to the sustained competitive advantage of the business.

The Process - Specific Condition. One source of the sustained competitive advantage is related to processing activities within a business. It is related to the deployment and the use of resources. Attention to the process makes it possible to produce high and different quality products and services. Hofer and Schendel (1978,p 25) noted that the unique position of a business developed against other business through resource deployment in the process activity.

Many things can be managed in the processing activities to have favorable product suiting with customer preferences. Mytelka \& Farinelli (2000) and Sarkar \& Costa (2008) emphasize the importance of innovation on the process activities. It is a new method resulting from competencies of people (Rastogi, 2000 and Man, Lau, \& Chan, 2002), new materials used (Johnson and Scholes, 2002), and the use of technology to reduce costs and/or produce high-quality food (Buckley, et al. 1988). It could also a way to provide attention to hygiene processing activities (Wang \& Yue, 2017). H3. The better the process, the more favorable the business-specific condition.

The relationship between activities on the process and the business condition has been recorded widely by numbers of literature. Attention provided in the process activities lead to improving the position of products in the eyes of consumers (Ray, Barney, \& Muhanna, 2004). A business that pays attention to the process could produce high-quality foods and beverage that will increase customer 
preferences (Covin \& Miles, 1999). Customers are able to identify the quality product through attribute attached in the products. Activity in the process is a source of putting the attribute in the product that will, in turn, produced innovative and unique food and beverage compared to other (Verhees \& Meulenberg, 2004).

H4. The better the process, the more sustained competitive advantage the business.

A business that pays attention to organizational process activities will have products that are sustained competitive advantages. Attention to processes is the way most companies do to increase competitiveness in the market (Ray, Barney \& Muhanna, 2004). Attention to the process can be emphasized on aspects of knowledge from human resources (Rastogi, 2000 and Man, Lau, \& Chan, 2002), technology (Piccoli \& Ives, 2005 and Buckley, et al. 1988), raw materials and auxiliary materials (Johnson and Scholes, 2002) and product hygiene (Chen, Lai, \& Wen, 2006).

H5: The better the process, the more innovative and attractive the product.

The Business-Specific Condition. Every food and beverage business have its own different characteristics between one business and another. The existing business tend to have a reputation better than a new one. A reputable business certainly has customers with a high frequency of purchasing behavior (Kang'ethe \& Wanambiro, 2016 and Lu \& Wang, 2016). The reputation not only built through product and processing activities but also it can be obtained from the business-specific condition. It is obviously different between the business accessible with various modes of transportation than those not easily accessible. In addition, the distinctive business from others can also be obtained convenient facilities provided since it could bring new customers and increase purchase frequencies (Min \& Min, 2011). It also occurred when a business to have various promotion mode through the internet. Customers will easily access and perceive company products from complete information obtained through the internet (Castleman \& Chin, 2002). Website and social media could be a way to disseminate product attributes to increase sales (Cetinkaya, 2009 and He, Zha \& Li, 2013).

Reputation of a food and beverage business can be separated from the business location. Some customer may prefer with a business that has adequate and convenient facilities (Porter, 2000 and Min \& Min, 2011).

H6: The Better the Business-Specific Condition, the more sustained competitive advantage the business is.

Business conditions can also affect sustained competitive advantages. Reputable businesses can generate high levels of sales on an ongoing basis compared to businesses that have no reputation (Kang'ethe \& Wanambiro, 2016 and Lu \& Wang, 2016). Reputation makes customers be loyal to products (Terblanche, 2014). Besides, the condition of the business place is also a concern by consumers. Consumers tend to buy food and beverage products in businesses that provide pleasant and comfortable facilities (Kozak \& Rimmington, 1998). In addition, the ease of access to business premises is likable by consumers. the consumers can come in anytime when accessible by transportation (Min \& Min, 2011). This could lead the frequency of purchasing behavior.

Information on products offered by food and beverage businesses also has a high influence on business continuity. New consumers will find it easy to recognize company products from internet information (Rousseau, 2012; Castleman \& Chin, 2002 and Cetinkaya, 2009). Consumers who have consumed company products can use the internet to make reorder of company products if they are satisfied (Castleman \& Chin, 2002;). This will increase business performance and in the long run, it will lead to sustained competitive advantages. 


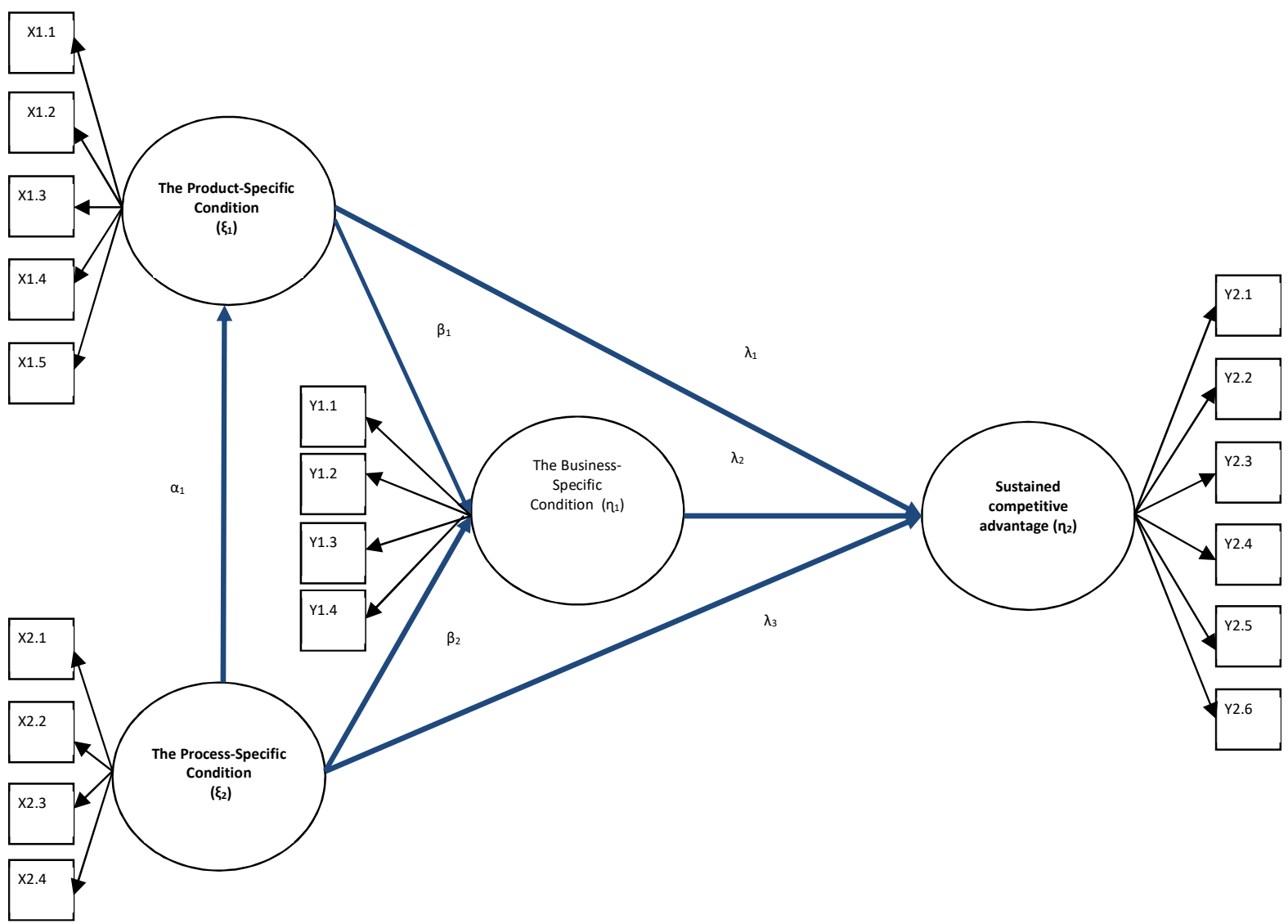

Figure 1. The Conceptual Proposed Model for SMEs of Food and Beverage in South Sulawesi

\section{Conclusion}

The condition of SMEs business competition of food and beverage in South Sulawesi is quite high. This is indicated by the number of existing businesses operating in that area, the ease of establishing a new business, the ease of exit from the business activity. These conditions reflect continuity problems faced by food and beverage business in the South and West Sulawesi. The issues are very crucial since SMEs of food and beverage provide a high contribution to the region. SMEs of food and beverage have a high connection with various businesses in the downstream, trader in the traditional market, commodity suppliers, and farmers. It is therefore, the study conducted a conceptual model with the use of literature and empirical evidence to build an integrated model.

On the basis of literature and empirical evidence, the study found that three construct latent variables that could affect sustained competitive advantage of SMEs food and beverage. The three variables are found to result six path hypotheses built to develop an integrated model of sustained competitive advantage. Each construct is measured by a number of indicators and the whole construct latent variables are reflected by 19 measurable variables.

\section{References}

Barney, J. B. (1986). Organizational culture: can it be a source of sustained competitive advantage?. Academy of management review, 11(3), 656-665.

Barney, J. (1991). Firm resources and sustained competitive advantage. Journal of management, 17(1), 99-120.

Bharadwaj, S. G., Varadarajan, P. R., \& Fahy, J. (1993). Sustainable competitive advantage in service industries: a conceptual model and research propositions. The Journal of Marketing, 83-99. 
Buckley, P., Pass, C., and Prescott, K. (1988). Measures of international competitiveness: a critical survey. Journal of Marketing Management, vol 4, 175-200.

Castleman, T., \& Chin, C. Y. P. (2002). eCommerce and the competitiveness of small enterprises: a study of the restaurant industry.

Cetinkaya, A. S. (2009, July). Destination competitiveness through the use of information and communication technologies. In European and Mediterranean conference on information systems (pp. 13-14).

Chen, Y. S., Lai, S. B., \& Wen, C. T. (2006). The influence of green innovation performance on corporate advantage in Taiwan. Journal of business ethics, 67(4), 331-339.

Covin, J. G., \& Miles, M. P. (1999). Corporate entrepreneurship and the pursuit of competitive advantage. Entrepreneurship theory and practice, 23(3), 47-63.

Diana, A. M. (2017). Pendapatan Usaha dan Beban Operasional Terhadap Laba Bersih Pada Perusahaan Makanan dan Minuman.. JWEM (Jurnal Wira Ekonomi Mikroskil), 7(2), 173-180

Eniola, A. A., \& Ektebang, H. (2014). SME firm's performance in Nigeria: Competitive advantage and its impact. International journal of Research studies in management, 3(2), 75-86.

Grekova, K., Calantone, R. J., Bremmers, H. J., Trienekens, J. H., \& Omta, S. W. F. (2016). How environmental collaboration with suppliers and customers influences firm performance: evidence from Dutch food and beverage processors. Journal of cleaner production, 112, 18611871.

Hall, R. (1993). A framework linking intangible resources and capabiliites to sustainable competitive advantage. Strategic management journal, 14(8), 607-618.

Han, S. H., Nguyen, B., \& Lee, T. J. (2015). Consumer-based chain restaurant brand equity, brand reputation, and brand trust. International Journal of Hospitality Management, 50, 84-93.

Hanaysha, J. (2016). Building brand equity through customer service: A study on restaurant industry in Malaysia. Journal of Research in Business, Economics and Management, 5(5), 678-685.

He, W., Zha, S., \& Li, L. (2013). Social media competitive analysis and text mining: A case study in the pizza industry. International Journal of Information Management, 33(3), 464-472.

Hendry, J. 2001. Economic contract versus social relationships as a foundation for normative stakeholder theory. Business Ethics: A European Review, 10: 223-232

Hendry, J. 2004. Between enterprise and ethics: Business and management in a bimoral society. New York: Oxford University Press.

Hofer, C. W \& Schendel, D (1978) Strategy Formulation Analytical Concept ST. Paul, MN West.

Hoffman, J., Hoelscher, M., \& Sorenson, R. (2006). Achieving sustained competitive advantage: A family capital theory. Family business review, 19(2), 135-145.

Indris, S., \& Primiana, I. (2015). Internal and external environment analysis on the performance of small and medium industries (Smes) in Indonesia. International journal of scientific \& technology research, 4(4), 188-198

Jauhari, J. (2014). Upaya pengembangan usaha kecil dan menengah (UKM) dengan memanfaatkan e-commerce. Jurnal Sistem Informasi, 2(1).

Johnson, G. and Scholes, K. (2002). Exploring Corporate Strategy: Text and Cases, 6th ed., Pearson Education Ltd, Harlow

Jones, T. M., Harrison, J. S., \& Felps, W. (2018). How applying instrumental stakeholder theory can provide sustainable competitive advantage. Academy of Management Review, pp 371-390.

Kang'ethe, R. W., \& Wanambiro, V (2016). Assessment of Core Competences Influencing Competitiveness of Event Management Firms in Nakuru County, Kenya.

Kozak, M., \& Rimmington, M. (1998). Benchmarking: destination attractiveness and small hospitality business performance. International Journal of Contemporary Hospitality Management, 10(5), 184-188.

Kristiyanti, Mariana. "Peran strategis usaha kecil menengah (UKM) dalam pembangunan nasional." Majalah Ilmiah Informatika 3, no. 1 (2012): 63-89. 
Kumar, V., \& Pansari, A. (2016). Competitive advantage through engagement. Journal of Marketing Research, 53(4), 497-514.

Latifah, S. W. (2016). Karakteristik Pelaku Ekonomi Penunjang Supply Chain Management UKM Pangan di Malang. In Proceding Seminar Nasional Univ, Taruma Negara.

Long, T. B., Looijen, A., \& Blok, V. (2018). Critical success factors for the transition to business models for sustainability in the food and beverage industry in the Netherlands. Journal of Cleaner Production, 175, 82-95.

Lu, H. T., \& Wang, Y. C. (2016). The Impact of Media Reputation on Customers Behavioral Intention-The Contextual Stepwise Approach. Filomat, 30(15), 4243-4252.

Man, T. W., Lau, T., \& Chan, K. F. (2002). The competitiveness of small and medium enterprises: A conceptualization with focus on entrepreneurial competencies. Journal of business venturing, 17(2), 123-142.

Maskell, P., \& Malmberg, A. (1999). Localised learning and industrial competitiveness. Cambridge journal of economics, 23(2), 167-185.

Matrutty, E. S., Franksisca, R., \& Damayanti, T. (2018). SMEs Competitiveness In An Integrated Economy: A Preliminary Study From Indonesia. Oradea J. Bus. Econ, 2, 7-16.

McWilliams, A., \& Siegel, D. S. (2011). Creating and capturing value: Strategic corporate social responsibility, resource-based theory, and sustainable competitive advantage. Journal of Management, 37(5), 1480-1495.

Meilani, Y. F. C. P., \& Simanjuntak, S. (2012). Faktor yang Mempengaruhi Minat Beli Produk Makanan dan Minuman Usaha Kecil Menengah Kabupaten Tangerang. Jurnal Manajemen dan Kewirausahaan, 14(2), 164-172.

Min, H., \& Min, H. (2011). Benchmarking the service quality of fast-food restaurant franchises in the USA: A longitudinal study. Benchmarking: An International Journal, 18(2), 282-300.

Mutunga, S. L., \& Minja, D. (2014). Generic strategies employed by food and beverage firms in Kenya and their effects on sustainable competitive advantage. International Journal of Business and Management Review, 2(6), 1-15.

Mytelka, L., \& Farinelli, F. (2000). Local clusters, innovation systems and sustained competitiveness. UNU/INTECH Discussion Paper, (2005).

Nugraha, H. S., \& Ariyanti, F. (2017). Penerapan Branding Pada UKM Makanan Ringan di Kabupaten Jepara. Jurnal Administrasi Bisnis, 6(1), 16-23.

Piccoli, G., \& Ives, B. (2005). IT-dependent strategic initiatives and sustained competitive advantage: a review and synthesis of the literature. MIS quarterly, 29(4), 747-776.

Porter, M. (1985). Competitive Advantage, Free Press, New York

Porter, M. E. (2000). Location, competition, and economic development: Local clusters in a global economy. Economic development quarterly, 14(1), 15-34.

Ray, G., Barney, J. B., \& Muhanna, W. A. (2004). Capabilities, business processes, and competitive advantage: choosing the dependent variable in empirical tests of the resource-based view. Strategic management journal, 25(1), 23-37.

Rastogi, P. N. (2000). Knowledge management and intellectual capital-the new virtuous reality of competitiveness. Human systems management, 19(1), 39-48.

Roberts, P. W., \& Dowling, G. R. (2002). Corporate reputation and sustained superior financial performance. Strategic management journal, 23(12), 1077-1093.

Rubio, N., Oubiña, J., \& Villaseñor, N. (2014). Brand awareness-Brand quality inference and consumer's risk perception in store brands of food products. Food quality and preference, 32, 289-298.

Rodriguez Perez, J., \& Ordóñez de Pablos, P. (2003). Knowledge management and organizational competitiveness: a framework for human capital analysis. Journal of Knowledge management, 7(3), 82-91.

Rousseau, S. (2012). Food and social media: You are what you tweet. Rowman Altamira. 
Salim, H. K., Padfield, R., Yuzir, A., Mohamad, S. E., Kaida, N., Papargyropoulou, E., \& Nakamura, S. (2018). Evaluating the organizational intention to implement an Environmental Management System: evidence from the Indonesian food and beverage industry. Business Strategy and the Environment.

Sarkar, S., \& Costa, A. I. (2008). Dynamics of open innovation in the food industry. Trends in Food Science \& Technology, 19(11), 574-580.

Sondakh, O., Christiananta, B., \& Ellitan, L. (2017). Measuring Organizational Performance: A Case Study of Food Industry SMEs in Surabaya-Indonesia. International Journal of Scientific Research and Management, 5(12), 7681-7689.

Sudaryanto, R., \& Wijayanti, R. R. (2013). Strategi pemberdayaan UMKM menghadapi pasar bebas Asean. Pusat Kebijakan Ekonomi Makro. Badan Kebijakan Fiskal. Kementerian Keuangan, Jakarta.

Terblanche, N. S. (2014). Validation of the customer-based corporate reputation scale in a retail context. International journal of Market research, 56(5), 655-671.

Tong, C., \& Wong, A. (2014). The influences of corporate social responsibility to customer repurchases intentions, customer word-of-mouth intentions and customer perceived food quality of fast-food restaurants in Hong Kong and the mediating effects of corporate reputation. British Journal of Economics, Management \& Trade, 4(11), 1655-1678.

Untaru, E. N., Ispas, A., \& NEACŞU, A. N. (2012). Perceptions of restaurant managers about the quality of products and services offered to consumers. Case study: the city of Brașov. Revista de turism-studii si cercetari in turism, (13).

Verhees, F. J., \& Meulenberg, M. T. (2004). Market orientation, innovativeness, product innovation, and performance in small firms. Journal of small business management, 42(2), 134-154.

Wang, J., \& Yue, H. (2017). Food safety pre-warning system based on data mining for a sustainable food supply chain. Food Control, 73, 223-229.

Yim, E. S., Lee, S., \& Kim, W. G. (2014). Determinants of a restaurant average meal price: An application of the hedonic pricing model. International Journal of Hospitality Management, 39, $11-20$

Yuli, S. B. C. (2006). Analisis Perubahan Lingkungan Terhadap Kompetensi Usaha (Studi pada Pengusaha Makanan dan Minuman Skala Kecil dan Menengah di Kabupaten Malang dan Pasuruan). Jurnal Humanity, 1(2). 